\title{
AKADEMINIS JAUNIMAS TAUTINIO APSISPRENDIMO KRYŽKELĖJE (EMPIRINĖ PRIEIGA)
}

\author{
Dalia Antinienè \\ Kauno technologijos universitetas, Kaunas, Lietuva
}

\begin{abstract}
Dalia Antinienè. Socialinių mokslų daktarè. Kauno technologijos universiteto Psichologijos katedros docentè. Mokslinių tyrimų kryptis — tau-
\end{abstract} tinis tapatumas, emigracinès nuostatos, socialinis tinklas, neigaliujų socializacija, kognityvieji gebėjimai.

\section{SANTRAUKA}

Šiame straipsnyje pristatomas Lietuvos studentu tautinio tapatumo nuostatu tyrimas. Tyrimo tikslas — nustatyti studentu tautinio tapatumo turinị ir raiškos ypatumus. Tyrimo metu kelti šie uždaviniai: atlikti reprezentatyvia Lietuvos studentu apklausq ir gautu duomenu statistinius skaičiavimus; fenomenologiškai ištyrineti studentu tautinio tapatumo struktūrq ir apibrèžti šalies kultūrini konteksta atitinkančius tautinio tapatumo rodiklius.

Tautiškumo nuostatos tirtos originaliu anoniminiu uždaro tipo klausimynu. Tautini tapatuma parodančios nuostatos konkretizuotos 33 teiginiais. Iš viso apklausta 712 studentu, besimokančiu 9 universitetuose, 2 kolegijose ir 2 aukštesniosiose mokyklose.

Faktorinès validacijos būdu išskirtos Lietuvos studentu tautinị tapatuma nusakančiu nuostatu dimensijos: ,, etnocentrizmas “, „, refleksyvus ir demokratinis “, „,nuosaikus ir racionalus “ požiūris i tautiškuma, ,, antietnocentristinès (salygiškai kosmopolitinès) nuostatos “, „, nacionalistinis požiūris į tautiškuma“. Taikant keliu pakopu faktorinès analizès modelius gauta, kad tautini tapatuma parodančios nuostatos gana aiškiai poliarizuojasi $\mathfrak{i}$ dvi, kartais viena kita paneigiančias dedamasias — „, modernu“ ir „, tradicini “ požiūrị i tautiškuma.

Visuminei identiteto struktūrai nustatyti naudotas daugiamačiu skaliu MDS (Multidimensional Scaling) metodas. MDS pagalba gautas tautinio tapatumo raiškos gradacijos modelis, kuriame akivaizdžiai atsiskleidžia keli studentu nuostatu kritiniai būviai.

Naudojant klasterinę analizę (K-Mean Cluster Analysis), tyrimo metu identifikuoti konkretūs studijuojančio jaunimo

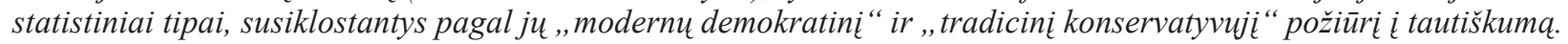
Paaiškejo, kad pagal požiūrị i tautiškumq egzistuoja pakankamai skirtingai profiliuotos studijuojančiojo jaunimo grupès. Gauti keturi Lietuvos studentu statistiniai tipai, susiklostantys pagal tautiškumo nuostatu raiškq: ,,modernistai“, kuriu santykinis paplitimas tarp šalies studentu siekia apie 14,9\%, ,etnocentristai“ “ $(21,3 \%)$, ,,dualistai“ $(27,5 \%)$ ir , ,abejingieji“" (36,3\%).

Raktažodžiai: tautinis tapatumas, socialinès nuostatos, kosmopolitizmas ir etnocentrizmas.

\section{IVADAS}

$\mathrm{V}$ ieningos, griežtai nusistovèjusios tautiškumo ir tautinio tapatumo, kaip tautiškumo referento, sąvokų sampratos socialiniuose moksluose kol kas nėra: visuomenei modernèjant, šios sąvokos nuolat evoliucionuoja igaudamos vis kitokią prasmę. Tautiškumas šio straipsnio kontekste traktuojamas kaip žmogaus identiteto išraiška, nusakanti jo santykị su pasauliu, kitomis tautomis, priklausomybę , „sivivaizduojamai“" žmo-

Remiantis B. Anderson terminologija, „tauta“ ir „tautiškumas“ yra dirbtinès sąvokos, ,kylančios iš naujų žiniasklaidos formų ir plintančios kartu su ekonomine modernizacija“ (Anderson, 1999). nių bendruomenei, išsiskiriančiai savo specifiniais bruožais ir saistomai labiau dvasiniais nei pragmatiniais ryšiais.

Gana artima tautiškumui - tautinio tapatumo sąvoka. Tautinis tapatumas dažnai suprantamas kaip tam tikra sąlygiškai stabili individo susikurta ar igyta būsena, susijusi su angažuotu, sąmoningu isitraukimu i tautos reikalus (Phinney 1989, 1990; Phinney, Rosenthal, 1992; Salazar, 1998 ir kt.). Tai dinamiškas, daugiamatis darinys, besiformuojantis ir funkcionuojantis pagal tam tikrus socialinius-psichologinius dèsnius ir atliekantis daugybe funkciju. Tapatumas bendrai, kartu ir tautinis tapatumas, yra susijęs su individualia refleksija, savo 
vietos ir vaidmens pasaulyje supratimu (Kroger, 2000; Blank, 2003; Abell et al., 2006).

Tautiškumo nuostatas galima apibūdinti kaip socialines, lemiančias asmens savo paties ir aplinkinio pasaulio samprata, vertinimus bei elgesi bet kurioje jo veiklos srityje: profesinèje, politinejje, kultūrineje ir pan., per priklausomybès tautinei grupei prizmę. Šiame straipsnyje sąvokos tautinis tapatumas ir tautini tapatumą parodančios nuostatos traktuojamos kaip sinonimai, nors platesniame kontekste jos nèra tapačios. Tautiškumo nuostatu sąvoka vartojama turint galvoje socialines nuostatas, nusakančias asmens tautini tapatumą.

Tautinio tapatumo sąvoka apima asmens pasirengimą igyti ar internalizuoti su tautiškumu susijusias nuostatas iš emocinių bei informaciniu šaltinių: mokyklos, bažnyčios, šeimos, politikų, žiniasklaidos ir kt. Taip suprantamas tautinis tapatumas gali kisti kontinuume nuo ryškiai pozityvaus (fašistinio-nacionalistinio) iki negatyvaus (kosmopolitinio) su centre esančia indiferentiška pozicija (Dekker, 2001).

Tautini tapatumą parodančių socialinių nuostatų mokslinè konceptualizacija pastaruoju metu yra ypač plati. Ko gero, tai lemia minèto fenomeno analizavimo iqvairove. Siekdami nustatyti pagrindines tautinio tapatumo nuostatu dimensijas, kai kurie tyrejjai tautinį tapatumą sieja su labai skirtingais fenomenais: pagarba tautos istorijai, paveldo saugojimu, gyvenamaja vieta, pasididžiavimu dèl tautiečių sportinių pergalių, požiūriu ị tautines mažumas ir pan. (Kosterman, Feshbach, 1989; Abell et al., 2006).

Šiuolaikinèse mokslinèse tautinio tapatumo studijose tiek užsienyje, tiek Lietuvoje galima ¡žvelgti aiškią takoskyrą: teorinei fenomeno analizei skirtus darbus ir menkai su jais susijusius empirinius tyrimus. Empiriniai tautinio tapatumo tyrimai užsienyje jau turi tam tikrą istoriją ir net nepaisant šio fenomeno tyrinèjimo metodologiniu sunkumų yra ypatingai gausūs (Giles et al. 1976; Phinney, 1990; Huddy, 2001; Sears, Henry, 1999; Citrin et al., 2000; Blank, 2003; Dekker et al., 2003; Muldoon et al., 2007; Transue, 2007 ir kt.). Lietuvoje tautiniu tapatumu domimasi, tačiau empiriniai tyrimai, lyginant su užsienyje vykdomais, vis dar yra gana skurdūs ir nenuoseklūs. Tai skatina gilintis $\mathfrak{i}$ tautinio tapatumo sriti, méginant atskleisti šiuolaikinio tautinio tapatumo bruožus ir veiksnius, kurie yra svarbūs asmens tapatumo formavimuisi.

Galima pastebèti, kad Amerikos, Vakaru Europos ir Lietuvos mokslininkų atliekami tautinio identiteto tyrimai gana ryškiai skiriasi. Pagrindinès vakariečių tautinio tapatumo problemos siejamos su asimiliacija ir integracija. Tuo tarpu Lietuvoje problemos kitokios - tai tautinio tapatumo silpnejjimas, emigracija ir pan. Todèl statistiniai dèsningumai ir teoriniai apibendrinimai, nustatyti kitose šalyse bei kultūrose, nors ir yra vertingi, negali būti perkeliami ir taikomi Lietuvos gyventojams. Svarbūs dabartines Lietuvos realijas atitinkantys tyrimai, kurie galètu padèti atskleisti kultūriškai specifišką tautinio tapatumo fenomeno raišką šalyje.

Taigi, viena vertus, tautinio fenomeno kultūrinis specifiškumas, kita vertus, jo empirinio atskleidimo galimybiu ivvairovè lèmè tai, kad pasirinktas tyrimo modelis, kuri naudojant analizuojama fenomenologiškai ịvestų požymių struktūra ir tokiu būdu mėginamos išskirti pagrindinès tautinio tapatumo dimensijos. Kultūriškai specifiškų, Lietuvos realijas atitinkančių tautinio tapatumo dimensijų išskyrimas ir jų raiškos įvertinimas yra pagrindinè mokslinè problema, sprendžiama šio tyrimo metu.

Tautinio tapatumo tyrimui pasirinkti Lietuvos studentai, t. y. intelektualioji jaunimo dalis, kurios tautinè socializacija aktyviai tebesitęsia. Tai žmonès, kurių tapatumas dar formuojasi ir kurie turi priimti labai svarbius sprendimus savo gyvenime: likti Lietuvoje ar emigruoti, puoselèti tautiškumą ar tapti „pasaulio piliečiais“. Jaunimo, kaip socialinės grupès, tautinio tapatumo tyrimas aktualus ne vien prognostiniu galimybių prasme, bet ir todèl, kad jaunimo tautinio tapatumo būvis nèra žinomas.

Tyrimo tikslas - nustatyti akademinio jaunimo tautinio tapatumo nuostatų turini ir raiškos ypatumus. Tyrimo klausimai: kokie konkretūs rodikliai apibūdina studentų tautinio tapatumo turinį? Kokia studentų tautinio tapatumo nuostatų raiška, kaip stipriai tautiškumas yra išreikštas pagal atskiras dimensijas? Tyrimo objektas — studentų tautini tapatumą parodančios nuostatos.

\section{TYRIMO METODAI}

Tiriamieji. Tautinį tapatumą nusakančių nuostatú tyrimo rezultatai gauti Lietuvos studijuojančiojo jaunimo populiacijoje. Renkantis lizdus atsižvelgta į tokius veiksnius kaip geografini, mokslo krypties, lygmens, aukštosios mokyklos prestižiškumo ir kitus. Apklausti universitetu (Vilniaus pedagoginio $(\mathrm{n}=106)$, Klaipėdos $(\mathrm{n}=98)$, Vytauto didžiojo $(\mathrm{n}=76)$, Kauno technologijos 
$(\mathrm{n}=72)$ universitetu, Aukštosios vadybos mokyklos (ISM) $(\mathrm{n}=55)$, VU Kauno humanitarinio fakulteto $(n=47)$, Kauno tarpdiecezinès kunigu seminarijos $(\mathrm{n}=32)$, KTU Panevèžio fakulteto $(n=29)$ ), kolegiju (Vakaru Lietuvos verslo $(\mathrm{n}=30)$, Marijampolès $(\mathrm{n}=29))$ ir aukštesniuju mokyklų (Panevéžio A. Domaševičiaus medicinos mokyklos $(\mathrm{n}=75)$, Kauno politechnikumo $(\mathrm{n}=24))$ studentai. Apklausta $80 \%$ bakalauro studijų ir $20 \%$ magistro lygmens studentų. $73 \%$ tiriamuju studijavo socialinius ir humanitarinius, $21 \%$ - inžinerinius ir 6\% - gamtos mokslus. Dauguma studentu, t. y. $92 \%(\mathrm{n}=654)$, yra lietuviai, likusieji $8 \%(n=58)$ - kitataučiai Lietuvos gyventojai. Nors tiriamujuc imties lietuvių ir nelietuviu santykis nèra proporcingas, bet jis rodo bendrą tautinès sudèties vaizdą Lietuvoje.

Iš viso apklausta 712 respondentų. Studentų imties demografinès charakteristikos tokios: vyru $39,6 \%$, moteru $60,4 \%$, amžius svyruoja nuo 18 iki 29 metu, vidurkis $-21,8$ metu, standartinis nuokrypis $\mathrm{SD}=4,84$ metu.

Metodika. Psichologijos moksle iki šiol nėra nustatyta vieningo tautinio tapatumo tyrimo metodo ir nèra išskirtos pagrindinès šio fenomeno dimensijos. Tiriant apsispręsta ši teoriškai abstraktų ir sudėtingą socialinit-psichologinį reiškini atskleisti per socialinių nuostatų tyrimo prizmę. Konstruojant matavimo instrumentą buvo siekiama, kad respondentų nuostatos atsiskleistu netiesiogiai, iš daugybès turinio prasme specialiai nenuosekliai pateikiamų teiginių. Taikant šią strategija, dirbama ne su pavieniais teiginiais, bet operuojama indeksais ir skalemis. Rengiant tyrimą pasirinktas penkių pakopų Likerto skalès atsakymo formatas nuo „visiškai sutinku“ iki „visiškai nesutinku“. Pavyzdžiui, „Tautinè priklausomybė man yra reikšminga“ — galimi atsakymai: „tikrai ne“, „lyg ir ne“, „nežinau“, „lyg ir taip“, „tikrai taip". Tautini tapatumą parodančios nuostatos konkretizuotos 33 teiginiais. Taikant faktorinę validaciją, šių teiginių (testo žingsnių) pagrindu, vèliau rengiamos skalès. Pirminiai teiginiai faktorinès analizès būdu sutankinti į 11 skalių.

Empirinis Lietuvos studentų tautinio tapatumo nuostatu tyrimas atliktas taikant anoniminę apklausą. Apklausa atlikta auditorijose, kuriose buvo 25-30 žmonių grupès. Anketos pildomos apie 30 min, anketų grižtamumo kvota siekè $92 \%$.

Respondentų duomenys apdoroti naudojant statistinius metodus: faktorinę, klasterinę analizę, daugiamates skales ir kt.

\section{REZULTATAI}

Socialinių nuostatų tyrimai susiję su daugybe problemų: viena jų - tyrimo struktūros parengimas, ypač teiginių formuluotès. Šio tyrimo metu, remiantis Lietuvos ir užsienio mokslininkų sukaupta patirtimi tautinio tapatumo tyrimų srityje, pateikta fenomenologiškai įvestų požymių struktūra, kuri vèliau analizuojama.

Kai kurių tyrejjų požiūriu, tautiškumo nuostatos formuojasi tam tikra nuoseklia tvarka: nuo neutralaus požiūrio ị tautiškumą dviem priešingomis kryptimis - pirma, link kosmopolitizmo, antra, link nacionalizmo (Dekker et al., 2003). Kadangi nuostatų spektras gali būti platus, tad konstruojant tyrimo struktūrą siekta aprèpti kuo daugiau tautini tapatumą parodančių rodiklių. Taigi socialinių nuostatų skalè sudaryta iš 33 testo žingsnių, kurių semantika atskleidžia įvairius, gana skirtingus tautinio tapatumo aspektus.

Faktorinè validacija tyrimo metu naudota kaip pagrindinis skalių sudarymo metodas. 1 lentelëje parodyta diagnostinio instrumento skaliu struktūra ir psichometrinès kokybès charakteristikos ${ }^{2}$. Instrumento kokybė svyruoja nuo labai geros iki patenkinamos. Turint omenyje, kad šio tyrimo metu analizuojami grupiniai, bet ne individualūs duomenys, gautu skalių psichometrinè kokybè yra priimtina.

Tautiškumo nuostatos, kaip ir kitos socialinès, kinta nuo teigiamo iki neigiamo poliaus, šiuo atveju - nuo kraštutinių nacionalistinių iki kosmopolitinių, todèl lentelèje skalès pateiktos mėginant šiek tiek laikytis nuoseklumo: nuo hipertrofuotai pozityviu (nacionalistiniu) iki negatyviausių (kosmopolitinių) nuostatų.

Siekiant aiškesnès ir labiau apibendrintos studentų tautinio tapatumo požymių struktūros, buvo atlikta tautiškumo nuostatų skalių vertinimo daugiapakopè faktorinè analizè. Aiškumo dèlei, rezultatai nėra pristatomi išsamiai ir nuosekliai, pagal nueitą ilgą tyrinėjimo kelią, bet pateikiamas gautas galutinis rezultatas, pasiektas atlikus visą grandinę faktorizacijų: kai kurias skales sujungiant, o kai kurias kategorijas, „griaunančias“ faktorinès analizès modelí, eliminuojant.

Galutiniai tautinio tapatumo nuostatu faktorinès analizès duomenys leidžia kalbèti apie ju dvimatę struktūrą (žr. 2 lent.). Nuostatos gana aiškiai poliarizuojasi $\mathfrak{i}$ dvi, kartais viena kitą panei-

\footnotetext{
Nurodyti statistiniai rodikliai: 1) Cronbach- $\alpha$ koeficiento reikšmès; 2) vidutinè interkoreliacija tarp testo žingsnių, taip pat minimali bei maksimali koreliacija; 3) i / tt — skiriamoji geba; 4) L — faktorinis svoris; 5) faktorinio modelio bendroji paaiškinta sklaida.
} 
1 lentelè. Tautiškumo nuostatų skalè

\begin{tabular}{|c|c|c|c|c|}
\hline $\begin{array}{c}\begin{array}{c}\text { Skalès (indekso) } \\
\text { dinimas }\end{array} \\
\end{array}$ & Skalëje apibendrinti teiginiai & $\mathbf{i} / \mathbf{t t}$ & $\mathbf{L}$ & $\%$ \\
\hline $\begin{array}{l}\text { „Nacionalistinis po- } \\
\text { žiūris į tautiškumą" }\end{array}$ & $\begin{array}{l}\text { - Man rūpi, kad Lietuva atgautu savo prarastas teritorijas }(\mathrm{M}=1,75, \mathrm{SD}=1,42) \\
\text { - Lietuvių tauta geresnè už kitas pasaulio tautas }(\mathrm{M}=1,18, \mathrm{SD}=1,20)\end{array}$ & & $\begin{array}{l}0,74 \\
0,69\end{array}$ & 12 \\
\hline $\begin{array}{l}\text { „Tautiškai angažuota } \\
\text { pozicija“ (subjektyvi } \\
\text { tautiškumo svarba } \\
\text { asmeniui) } \\
\alpha=0,67 \\
0,36 \\
0,14-0,50\end{array}$ & $\begin{array}{l}\text { - Aš esu Lietuvos patriotas }(\mathrm{M}=2,16, \mathrm{SD}=1,35) \\
\text { - Tautinė priklausomybė man yra reikšminga }(\mathrm{M}=2,54, \mathrm{SD}=1,31) \\
\text { - Aš manau, kad žmogui svarbu būti vienos ar kitos tautos atstovu }(\mathrm{M}=3,15 \text {, } \\
\mathrm{SD}=1,14) \\
\text { - Mano šeimoje visuomet buvo puoselëjamas tautiškumas }(\mathrm{M}=2,15, \mathrm{SD}=1,32)\end{array}$ & $\begin{array}{l}0,57 \\
0,50 \\
0,33 \\
0,43\end{array}$ & $\begin{array}{l}0,76 \\
0,74 \\
0,64\end{array}$ & 28 \\
\hline $\begin{array}{l}\text { „Tautišku } \\
\text { asmeniui }\end{array}$ & $\begin{array}{l}\text { - Tautiškumas turi įtakos mano pažiūroms, gyvenimo filosofijai }(\mathrm{M}=1,95 \text {, } \\
\mathrm{SD}=1,35) \\
\text { - Tautiškumas turi įtakos mano elgesiui, gyvenimo tikslams }(\mathrm{M}=2,04, \mathrm{SD}=1,32)\end{array}$ & & $\begin{array}{l}0,88 \\
0,87\end{array}$ & 13 \\
\hline $\begin{array}{l}\text {,Kultūriniai ir pilie- } \\
\text { tiniai insipareigojimai } \\
\text { tautai“" } \\
\alpha=0,84 \\
0,37 \\
0,12-0,58\end{array}$ & $\begin{array}{l}\text { - Man rūpi tautiškumo išlaikymas ir tradicijų puoselèjimas }(\mathrm{M}=2,99, \mathrm{SD}=1,09) \\
\text { - Man rūpi lietuvių kalbos saugumas }(\mathrm{M}=3,18, \mathrm{SD}=1,05) \\
\text { - Kiekvieno lietuvio pareiga saugoti tautos orumą }(\mathrm{M}=3,26, \mathrm{SD}=0,93) \\
\text { - Man rūpi lietuvių tautos dabartis ir ateitis }(\mathrm{M}=3,39, \mathrm{SD}=0,85) \\
\text { - Man rūpi Lietuvos teritorijos saugumas }(\mathrm{M}=3,27, \mathrm{SD}=1,03) \\
\text { - Kiekvieno lietuvio pareiga priešintis tautiškumo menkinimui }(\mathrm{M}=3,23, \\
\mathrm{SD}=0,96) \\
\text { - Aš jaučiuosi įsipareigojęs ginti lietuvių tautą }(\mathrm{M}=2,39, \mathrm{SD}=1,25) \\
\text { - Aš domiuosi Lietuvos praeitimi, istorija }(\mathrm{M}=2,82, \mathrm{SD}=1,19) \\
\text { - Aš nerimauju, kad Lietuva greitai nutautès }(\mathrm{M}=2,19, \mathrm{SD}=1,41)\end{array}$ & $\begin{array}{l}0,67 \\
0,64 \\
0,64 \\
0,55 \\
0,66 \\
0,57 \\
0,54 \\
0,41 \\
0,34\end{array}$ & $\begin{array}{l}0,75 \\
0,72 \\
0,72 \\
0,68 \\
0,64 \\
0,64 \\
0,56 \\
0,55 \\
0,39\end{array}$ & 28 \\
\hline $\begin{array}{l}\text { „Identifikacija kaip } \\
\text { socializacijos ir } \\
\text { adaptacijos išdava“ } \\
\alpha=0,71 \\
0,33 \\
0,25-0,46\end{array}$ & $\begin{array}{l}\text { - Mano manymu, žmogaus tautybę lemia emocinis ryšys su tauta }(\mathrm{M}=0,35 \text {, } \\
\mathrm{SD}=0,48) \\
\text { - } \text { Mano manymu, žmogaus tautybę lemia orientacija ị tautos kultūrines tradicijas } \\
(\mathrm{M}=0,37, \mathrm{SD}=0,48) \\
\text { - Mano manymu, žmogaus tautybę lemia auklejimas tautos tradicijų dvasia } \\
(\mathrm{M}=0,40, \mathrm{SD}=0,49) \\
\text { - Mano manymu, žmogaus tautybę lemia susirūpinimas savo valstybe }(\mathrm{M}=0,22 \text {, } \\
\mathrm{SD}=0,41) \\
\text { - Mano manymu, žmogaus tautybę lemia dalyvavimas tautos politiniame gyvenime } \\
(\mathrm{M}=0,14, \mathrm{SD}=0,35)\end{array}$ & $\begin{array}{l}0,46 \\
0,50 \\
0,46 \\
0,48 \\
0,44\end{array}$ & $\begin{array}{l}0,74 \\
0,72 \\
0,66 \\
0,63 \\
0,53\end{array}$ & 29 \\
\hline & $\begin{array}{l}\text { - Mano manymu, žmogaus tautybę lemia tèvų tautybè (kilmė) }(\mathrm{M}=0,86 \text {, } \\
\mathrm{SD}=0,34)\end{array}$ & & & \\
\hline $\begin{array}{l}\text { „Topografinis veiks- } \\
\text { nys“ }\end{array}$ & nymu, žmogaus tautybę lemia gyvenamoji vieta $(\mathrm{M}=0,50, \mathrm{SD}$ & & & \\
\hline $\begin{array}{l}\text { „Kalbinis (lingvisti- } \\
\text { nis) veiksnys“ }\end{array}$ & $\bullet \mathrm{Ma}$ & & & \\
\hline $\begin{array}{l}\text { "Tautiškumo reflek- } \\
\text { sija“" } \\
\alpha=0,65 \\
0,38 \\
0,31-0,43\end{array}$ & $\begin{array}{l}\text { - Aš dažnai pamąstau apie savo tautinę priklausomybę dabar }(\mathrm{M}=1,27, \mathrm{SD}=1,38) \\
\text { - Anksčiau aš dažnai svarstydavau savo tautiškumo klausimą }(\mathrm{M}=0,73, \mathrm{SD}=1,08) \\
\text { - Kartais aš pamąstau apie tai, kas lemia žmogaus tautybę arba, kitais žodžiais } \\
\text { tariant, nuo ko priklauso, kad žmogus yra lietuvis, rusas, lenkas ir t. t. }(\mathrm{M}=1,62 \text {, } \\
\mathrm{SD}=1,44)\end{array}$ & $\begin{array}{l}0,51 \\
0,44 \\
0,42\end{array}$ & $\begin{array}{l}0,81 \\
0,76 \\
0,73\end{array}$ & 59 \\
\hline $\begin{array}{l}\text { "Tautinis apsispren- } \\
\text { dimas“ }\end{array}$ & - Aš manau, kad žmogus gali pasirinkti tautybę $(\mathrm{M}=1,94, \mathrm{SD}=1,60)$ & & & \\
\hline $\begin{array}{l}\text { "Antietnocentrinès“ } \\
\text { (sąlygiškai kosmo- } \\
\text { politinès) nuostatos } \\
\alpha=0,53 \\
0,22 \\
0,09-0,34\end{array}$ & $\begin{array}{l}\text { - Aš privengiu kalbėti apie tautiškumą, nes tai mane erzina }(\mathrm{M}=1,00, \mathrm{SD}=1,20) \\
\text { - Aš manau, kad Lietuvai atgavus nepriklausomybę tautiškumas prarado savo vertę } \\
(\mathrm{M}=1,66, \mathrm{SD}=1,40) \\
\text { - Tautiškumas man reikšmingas tik tam tikrais gyvenimo momentais }(\mathrm{M}=1,90, \\
\mathrm{SD}=1,43) \\
\text { - Patriotiškumą } 21 \text {-ame amžiuje aš vertinu kaip žingsni atgal, todėl mane erzina } \\
\text { kalbos apie patriotiškumą }(\mathrm{M}=1,32, \mathrm{SD}=1,27)\end{array}$ & \begin{tabular}{|l}
0,33 \\
0,44 \\
0,31 \\
0,20
\end{tabular} & $\begin{array}{l}0,67 \\
0,64\end{array}$ & 21 \\
\hline
\end{tabular}


2 lentelè. Tautinį tapatumą parodančių nuostatų galutiniai daugiapakopès faktorinès analizès duomenys

\begin{tabular}{|c|c|c|c|c|}
\hline Faktoriai & \multicolumn{2}{|c|}{$\begin{array}{l}1 \text { faktorius } \\
27,8 \%\end{array}$} & \multicolumn{2}{|c|}{$\begin{array}{l}2 \text { faktorius } \\
23,3 \%\end{array}$} \\
\hline Skalès (indeksai) & $\begin{array}{c}\text { Tradicinis } \\
\text { tautiškumas } \\
\text { L }\end{array}$ & Cronbach- $\alpha$ & $\begin{array}{c}\text { Modernus } \\
\text { tautiškumas } \\
\text { L }\end{array}$ & Cronbach- $\alpha$ \\
\hline „Etnocentrizmas“ (15 testo žingsniu) & 0,74 & 0,88 & $-0,35$ & \\
\hline $\begin{array}{l}\text { „Nacionalistinis“ požiūris į tautiškumą ( } 2 \text { testo } \\
\text { žingsniai) }\end{array}$ & 0,56 & - & $-0,02$ & \\
\hline $\begin{array}{l}\text { „Nuosaikus ir racionalus“ požiūris i tautinị apsis- } \\
\text { prendimą ( } 7 \text { testo žingsniai) }\end{array}$ & 0,53 & 0,71 & 0,16 & \\
\hline $\begin{array}{l}\text { „Refleksyvus ir demokratinis“" požiūris i tautišku- } \\
\text { mą ( } 5 \text { testo žingsniai) }\end{array}$ & 0,39 & & 0,72 & 0,47 \\
\hline $\begin{array}{l}\text { „Antietnocentrizmas (sąlyginis kosmopolitizmas)“ } \\
\text { (4 testo žingsniai) }\end{array}$ & $-0,33$ & & 0,71 & 0,53 \\
\hline Bendras testo žingsnių skaičius 33 & & 0,83 & & 0,53 \\
\hline
\end{tabular}

3 lentelè. Studentų pritarimo tautiškumo nuostatoms reitingas, sudarytas pagal atskiras sritis: „etnocentrizmą“, „refleksyvų ir demokratinị“, „nuosaikų ir racionalų“ požiūrị ị tautinị apsisprendimą, ,antietnocentrizmą“ ir ,nacionalizmą“

\begin{tabular}{|c|c|c|c|c|c|c|c|}
\hline \multirow[t]{2}{*}{ Subskalių (indeksų) pavadinimai } & $\begin{array}{l}\text { Teiginių } \\
\text { skaičius }\end{array}$ & Vidurkis & $\begin{array}{l}\text { Standart. } \\
\text { paklaida }\end{array}$ & $\begin{array}{l}\text { Standart. } \\
\text { nuokrypis }\end{array}$ & $\begin{array}{l}\text { Min. } \\
\text { pritari- } \\
\text { mas }\end{array}$ & $\begin{array}{c}\text { Maks. } \\
\text { pritarimas }\end{array}$ & $\begin{array}{l}\text { Vidutinis } \\
\text { pritarimas }\end{array}$ \\
\hline & Vnt. & M & SD & SE & $\%$ & $\%$ & $\%$ \\
\hline „Etnocentrizmas“ & 15 & 2,47 & 0,73 & 0,03 & 43,1 & 92,3 & 67,7 \\
\hline $\begin{array}{l}\text { „Refleksyvus ir demokratinis“" } \\
\text { požiūris į tautiškumą }\end{array}$ & 5 & 1,98 & 0,66 & 0,02 & 9,9 & 86,7 & 53,3 \\
\hline $\begin{array}{l}\text { „Nuosaikus ir racionalus“ požiūris } \\
\text { i tautinį apsisprendimą }\end{array}$ & 7 & 1,64 & 0,80 & 0,03 & 14,6 & 55,1 & 34,9 \\
\hline $\begin{array}{l}\text { „Antietnocentrinės“ nuostatos } \\
\text { (sąlygiškai „kosmopolitinès“) }\end{array}$ & 4 & 1,42 & 0,85 & 0,03 & 13,9 & 44,4 & 26,8 \\
\hline $\begin{array}{l}\text { „Nacionalistinis“" požiūris į tau- } \\
\text { tiškumą }\end{array}$ & 2 & 1,30 & 0,99 & 0,04 & 8,4 & 26,4 & 17,4 \\
\hline
\end{tabular}

Pastaba. $\mathrm{N}_{\text {min. }}=697, \mathrm{~N}_{\text {maks. }}=712$.

giančias dedamąsias — „tradicinị“ ir „modernu““ požiūrị i tautiškumą. Reikia pastebèti, kad faktorinès analizès duomenų statistinis tinkamumas yra toleruotinas. KMO rodiklis siekia 0,50 , taigi jis nėra aukštas, bet paaiškintos sklaidos rodikliai pakankami. Visas dviejų faktorių modelis paaiškina $51,1 \%$ tiriamų požymių sklaidos.

Faktoriuje susitelkusius kintamuosius galima interpretuoti teoriškai. Gautas modelis yra ir teoriškai prasmingas, ir statistiškai grynas. 2 lenteleje matyti, kad pirmo faktoriaus kintamieji gana aiškiai semantiškai parodo „tradicinị“ požiūrị i tautiškumą, o antro sutankinti kintamieji — ,modernu“. I pirmą faktorių patenka tokios skalès kaip „etnocentristinis“ (gautas sujungus „tautiškai angažuotos pozicijos“, „tautiškumo įtakos asmeniui“" ir „kultūrinių bei pilietiniu isipareigojimų tautai“ skales (Cronbach- $\alpha-0,86)$ ), ,nacionalistinis“ ir „nuosaikus ir racionalus“ požiūris į tautinị apsisprendimą (gautas sujungus ,identifikacijos, kaip socializacijos ir adaptacijos išdavos“, „lingvistinio veiksnio“ ir „topografinio veiksnio“ skales (Cronbach- $\alpha-0,70)$ ), i antra — „refleksyvus ir demokratinis“ (gautas sujungus „tautiškumo refleksijos“, „genetinio veiksnio“ ir „tautinio apsisprendimo" skales (Cronbach- $\alpha-0,50)$ ) ir „antietnocentristinis“ požiūris į tautiškumą. Reikia pastebèti, kad skalèms suteikti sąlygiški (darbiniai) pavadinimai, kurių konotacija gali šiek tiek skirtis nuo tradicinès moksle vartojamos prasmès.

Kiekvienas tautiškumo skalès teiginys ir kiekviena faktorinès analizès būdu sutankinta skale leidžia įvertinti tam tikrą tautinio tapatumo dimensiją. Pritarimo tautiškumo nuostatų skalėms statistiniai duomenys ir pritarimo reitingai pateikti 3 lentelèje.

Tyrimo metu nustatyta, kad studentu vidutinis pritarimo procentas teiginiams, parodantiems „tradicinị“ $(50,4 \%)$ ir „modernų“ $(48,3 \%)$ požiūrị i tautiškumą, yra gana panašus. 


\section{REZULTATŲ APTARIMAS}

Faktorinès analizès metodai leido nustatyti asmens tautinio tapatumo vidaus struktūrą. Tačiau prasminga ieškoti ir apibendrintos, visuminès identiteto struktūros. Tai galima padaryti visus tautinio tapatumo kintamuosius nagrinejjant vienu metu. Šiam uždaviniui igyvendinti naudojamas daugiamačių skalių metodas (MDS).

I MDS modeli itrauktos trys skalès, parodančios „tradicini“" požiūri i tautiškumą (,etnocentrizmą", „,nacionalistinị“ požiūrị i tautiškumą ir ,,nuosaikų ir racionalų“ požiūrị i tautinį apsisprendimą) ir dvi skalès — „modernuji““ (,antietnocentrizmą ar sąlygini kosmopolitizma““ bei „refleksyvų ir demokratinị" požiūrị i tautiškumą). MDS rezultatai, besiremiantys gana aukštu modelio statistiniu grynumu $($ Stress $=0,09, \mathrm{RSQ}=0,97)$, pateikti 1 paveiksle.

Kaip matyti, MDS rezultatai atskleidžia prasmingą nagrinėjamų požymių kompleksinę struktūrą. Pasitelkus šị modelị, gautas psichosemantines dimensijas galima teoriškai interpretuoti, ìvardijant $\mathrm{x}$ ir y ašis. Šiuo atveju abscisių aši sąlygiškai galima vadinti „socialinio priimtinumo“ dimensija, ordinačiu — ,antietnocentrizmo (kosmopolitizmo) prieš nacionalizmą" dimensija.

Matyti, kad vertikaliosios (ordinačių) ašies atžvilgiu labiausiai vienas nuo kito nutolę ,antietnocentristinis (kosmopolitinis)“ ir „nacionalistinis“" požiūris į tautiškumą. Šiu skalių nutolimas erdvejje patvirtina jų poliškumą. Tarp šių dviejų polių logiška seka išsirikiavusios visos kitos tautini tapatumą parodančios nuostatų dimensijos. Taigi gautą skalę galima interpretuoti kaip nuoseklią tautinio tapatumo skalę, besitęsiančią nuo kraštutinio ,antietnocentristinio (kosmopolitinio)“, „refleksyvaus demokratinio“, „nuosaikaus racionalaus“, „,etnocentristinio“ iki kito kraštutinio „nacionalistinio" požiūrio i tautiškumą. Galima teigti, kad gautas tautinio tapatumo raiškos gradacijos modelis rodo kelis Lietuvos studentų nuostatų kritinius būvius. Šis modelis akivaizdžiai atskleidžia tautinio tapatumo raiškos kultūrini specifiškumą. Apie tai leidžia spręsti tautinio tapatumo tyrimu analizè, pavyzdžiui, amerikietiškoje kultūroje. Kadangi Amerikos mokslininkai kosmopolitizmą supranta labiau kaip normą, tai jų tyrimai akcentuoja etnocentrizmo poliams atstovaujančias tautinio tapatumo kritines gradacijas (Kosterman, Feshbach, 1989; Blank, Schmidt, 2003). Lietuvos gyventoju istorine patirtis yra susiklosčiusi taip, kad į atsiribojimą nuo tautiškumo, kosmopolitizmą žiūrima kaip i negatyvų reiškinị. Todèl lietuviu ir amerikiečių tautiškumo raiškos gradacijų modeliu atskaitos taškai aiškiai nesutampa.

Tautinio tapatumo raiškos gradacijos modelis atskleidžia nuoseklią Lietuvos studentų tautinio tapatumo raiškos laipsniu seką. Nors šis modelis tarytum atskleidžia trivialią tiesą, bet jis kartu yra ir labai svarbus metodologinio konstrukto validumo irodymas.

Horizontaliojoje (abscisių) ašyje taip pat matyti ryškus poliškumas. Išryškejja dvi priešybès, kurias vienija socialinio priimtinumo-nepriimtinumo dimensija. „Nacionalistinis“ ir „antietnocentristinis (sąlygiškai kosmopolitinis)" požiūriai i tautiškumą patenka ị skirtingus diagramos erdvès plotus, lyginant su „etnocentristiniu“, „,nuosaikiu—racionaliu“ ir „refleksyviu demokratiniu“. MDS skalès kairèje pusẻje matyti socialiai patrauklesni, priimtinesni požiūriai i tautiškumą, kurie nuo ašių centro yra nutolę apytikriai per 1 punktą. Šiai grupei priklauso „etnocentristinis“, „nuosai-

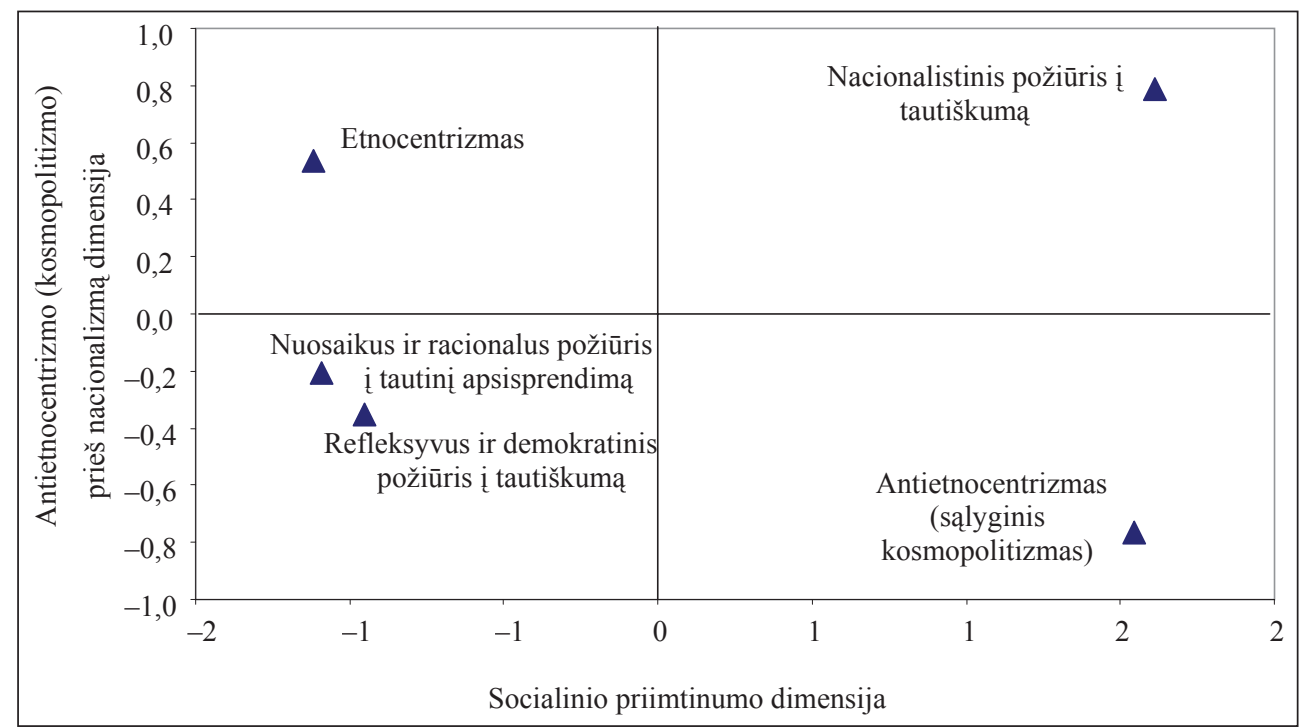

1 pav. MDS modelis 
2 pav. Studentų statistiniai tipai, susiklostantys pagal „modernų demokratinị“ ir „tradicinį konservatyvų“" požiūrị i tautiškumą

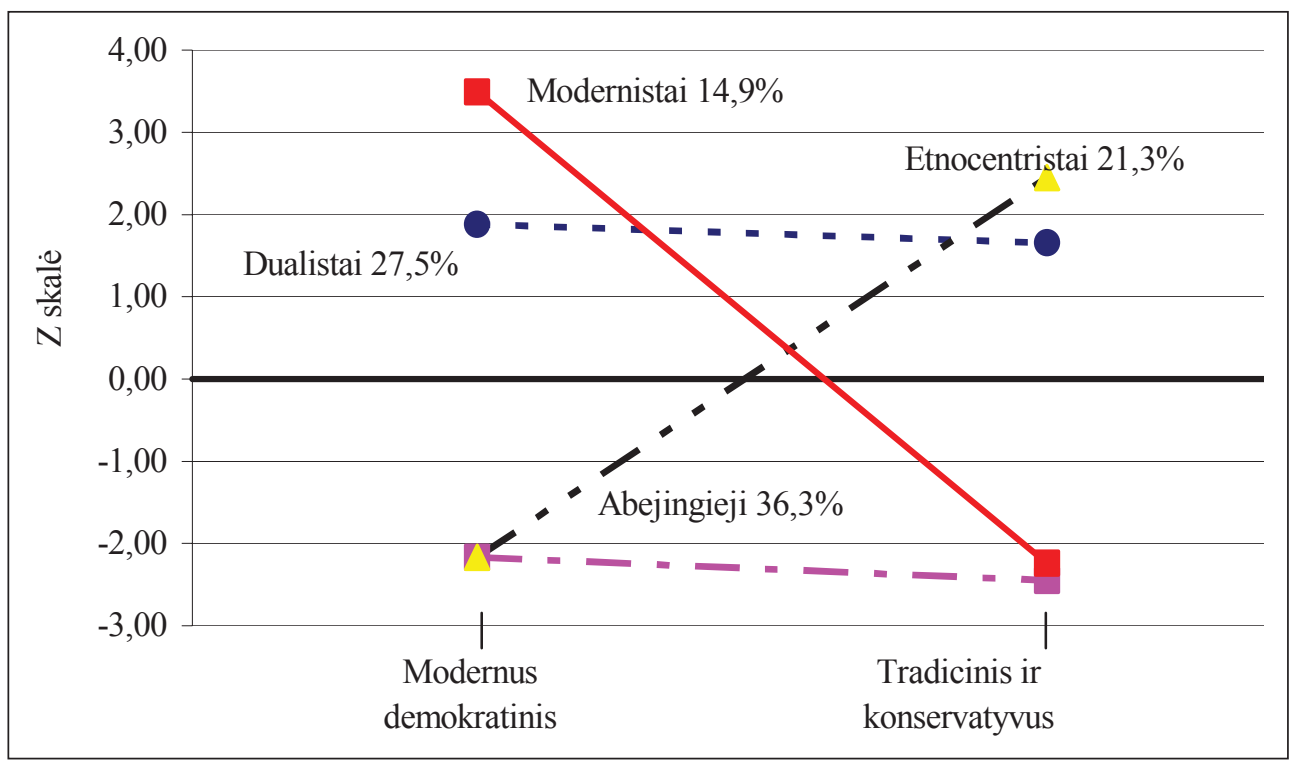

kus-racionalus“ ir „refleksyvus demokratinis“ požiūris ỉ tautini apsisprendimą. Dešinèje, nutolę nuo ašių net per 2 punktus, yra „nacionalistinis“ ir „kosmopolitinis“" požiūriai. Taigi „nacionalizmas“ ir ,antietnocentrizmas (sąlyginis kosmopolitizmas)“, kaip matyti, supanašèja socialinio priimtinumo prasme. Skirtumas tarp socialiai patraukliu ir nepatrauklių tautiškumo pozicijų - nemenkas, siekia net apie 3 punktus.

Taigi gautas MDS modelis pagal tiriamuju požiūrị i tautiškumą leidžia pagrịstai kalbèti apie asmens angažavimosi tautybei skalę nuo vienos iki kitos kraštutinès pozicijos (nuo „nacionalizmo“ iki „antietnocentrizmo (sąlyginio kosmopolitizmo)“) ir apie skalę požiūriu i tautiškumą socialinio priimtinumo prasme (nuo socialiai priimtino „etnocentristinio“ iki nepriimtino „nacionalistinio“).

Naudojant klasterinę analizę ( $K$-Mean Cluster Analysis), tyrimo metu bandoma identifikuoti konkrečius studijuojančio jaunimo statistinius tipus, susiklostančius pagal jų „modernų demokratinị“ ir „tradicinị konservatyvų“ požiūrị i tautiškumą. Klasterizacijos rezultatai pateikti 2 paveiksle. Paaiškejjo, kad pagal požiūri i tautiškumą egzistuoja keturios pakankamai skirtingai profiliuotos studijuojančiojo jaunimo grupès.

Grupę, sąlygiškai pavadintą „modernistais“, sudaro mažiausias tiriamuju skaičius (14,9\%). Šios grupès studentu , modernus demokratinis“ požiūris į tautiškumą išreikštas stipriai, o „tradicinis konservatyvus" silpnai. Šiam tipui priklausantys asmenys i tautiškumą, ko gero, linkę žiūrèti gana paviršutiniškai. Jie nèra tautiškai angažuoti, nesijaučia savo šalies patriotais, nevertina tradiciniu tautiniu vertybių. Komentuojamam tipui priklau- santys asmenys, regis, labiausiai jaučiasi esą „pasaulio piliečiais“. Galima daryti prielaidą, kad savo gerovę jie sieja ne su dvasinėmis vertybèmis, o su materialinių poreikių tenkinimu („mano tèvynè ten, kur man gerai").

Penktadaliui tiriamujų (21,3\%) būdingos priešingos charakteristikos. Ši grupè sąlygiškai vadinama „etnocentristais“. Jie laikosi „tradicinio“ požiūrio į tautiškuma, o „modernus demokratinis“" požiūris išreikštas silpnai. Asmenys, priklausantys šiai grupei, yra stipriai tautiškai angažuoti, isipareigoję tautai, pripažistantys tautines vertybes ir tradicijas. „Etnocentristų“ elgesiui, pažiūroms, gyvenimo filosofijai, tikslams didžiulę įtaką daro tautiškumas. Juos sieja stiprus emocinis ryšys su tauta. Jie mano esą tautos patriotais, nerimauja dèl Lietuvos ateities ir savo ateiti sieja su ja.

Studentu grupè, kurioje pakankamai stipriai išreikštas tiek „modernus“, tiek „tradicinis“ požiūris i tautiškumą, vadinama „dualistais“. Šiam statistiniam tipui priskirta daugiau kaip ketvirtadalis tiriamujų $(27,5 \%)$. Šių asmenų pažiūrų struktūra rodo dualistini pradą. Jų nuomonė apie tautiškumą nevienareikšmiška. Nors jų požiūris, viena vertus — „tradicinis“, kita vertus — „modernus", tačiau abiem atvejais gana ryškiai išreikštas. Taigi galima tikètis, kad tautiškumo prasme tai pats lanksčiausias tipas. Tokie asmenys linkę laikytis tradicinių bendruomeninių vertybių, tačiau nèra pernelyg konservatyvūs arba etnocentristiški. Jiems svarbus tautiškumas, jie paiso tautiniu vertybių, bet nėra aklai susisaistę tautine priklausomybe. Galima speti, kad šie asmenys mato bei supranta globalizacijos procesus ir kartu jaučiasi laisvi savo sprendimais. 
Gausiausiai tiriamuju grupei būdingas silpnai išreikštas bet koks požiūris i tautiškumą - tai tautiniu požiūriu indiferentiška grupè. Matyt, pagrịstai ši grupé pavadinta ,abejingaisiais“ (36,3\%). Šios grupès tiriamujų gausą galbūt paaiškintų gana paprastas pavyzdys. Kaip žinoma, tautiškumas ir pilietiškumas yra glaudžiai susiję, o pastaruoju metu kaip tik pastebimas ryškiai susilpnèjęs jaunimo pilietiškumas, atsiskleidžiantis beveik per kiekvienus rinkimus ar referendumą. Todèl gautas rezultatas neturètu stebinti. Tačiau klausimas, kodèl studentai tautiškumui abejingi, nèra paprastas. Aiškinantis ši reiškini galima kelti tik kai kurias hipotetines prielaidas, pavyzdžiui: galbūt aplinka tautiškumo neišugdo, galbūt jaunimas jaučiasi nusivylęs, praradęs tikejjimą fundamentaliomis bendruomeninèmis vertybèmis ir pan.

Baigiant galima pastebèti, kad tyrimo metu gauta prasmingai interpretuojamos faktinès medžiagos apie Lietuvos studentų tautinio tapatumo raišką, tautini tapatumą parodančiu nuostatu lygius, ju poliarizaciją. Ateityje būtų tikslinga atskleisti išorinius veiksnius ir nepriklausomus kintamuosius, paaiškinančius tautinio tapatumo raišką tarp studentų.

\section{IŠVADOS}

1. Pasiteisino pasirinktas natūralios populiacijos individualių socialinių nuostatų tyrimas ano- niminiu klausimynu. Tai leidžia identifikuoti statistiškai gryną ir teoriškai interpretuojamą tautinio tapatumo nuostatų struktūra.

2. Empirinis nuostatu tyrimas parodè, kad tautinis tapatumas sudètingas, daugiamatis darinys. Faktorinès validacijos būdu išskirti studentų tautinio tapatumo nuostatų rodikliai: „nacionalistinis“ požiūris į tautiškumą, ,etnocentrizmas“, „nuosaikus ir racionalus“" požiūris ị tautini apsisprendima, „refleksyvus ir demokratinis“ požiūris ir ,antietnocentrizmas (sąlyginis kosmopolitizmas)“.

3. Kompleksiniame tautini tapatumą parodančiu nuostatu struktūros modelyje, gautame taikant daugiapakopę faktorinę analizę, išryškejjo apibendrinta dvimatè jų struktūra. Nuostatos gana aiškiai poliarizavosi i „tradicinio“ ir „modernaus" tautiškumo dedamąsias.

4. Naudojant multidimensinę skalę (MDS), gautas studentų tautinio tapatumo raiškos gradacijos modelis, kuris parodo tautiškumo būvių seką: „nacionalistini““, „etnocentristini““, „nuosaikų ir racionalų", „refleksyvu ir demokratini" bei „antietnocentristini (sąlygiškai kosmopolitini)“ požiūri i tautiškumą.

5. Tautinio identiteto prasme egzistuoja tipologinè ivairovè. Klasterinès analizès būdu gauti keturi studentų statistiniai tipai, susiklostantys pagal tautiškumo nuostatų raišką: ,,modernistai“, „etnocentristai“, „,dualistai“ ir ,abejingieji““ .

\section{LITERATŪRA}

Abell, J., Condor, S., Stevenson, C. (2006). „We are an island": Geographical imagery in accounts of citizenship, civil society, and national identity in Scotland and in England. Political Psychology, 27 (2), 207-226.

Anderson, B. (1999). Isivaizduojamos bendruomenès (apmastymai apie nacionalizmo kilmę bei plitima). Vilnius: Baltos lankos.

Blank, T. (2003). Determinants of national identity in East and West Germany: An empirical comparison of theories on the significance of authoritarianism, anomie, and general self-esteem. Political Psychology, 24 (2), 259-288.

Blank, T., Schmidt, P. (2003). National identity in a United Germany: Nationalism or patriotism? An empirical test with representative data. Political Psychology, 24 (2), $289-306$.

Citrin, J., Wong, C., Duff, B. (2000). The meaning of American national identity: Patterns of ethnic conflict and consensus. In R. Ashmore, L. Jussim, D. Wilder (Eds.), Social Identity, Inter-Group Conflict and Conflict Resolution (pp. 71-101). New York: Oxford University Press.

Dekker, H., Malova, D., Hoogendorn, S. (2003). Natio- nalism and its explanations. Political Psychology, 24 (2), $345-377$.

Dekker, H. (2001). Nationalism, its conceptualization and operationalization. In K. Phalet, A. Orkeny (Eds.), Ethnic Minorities and Interethnic Relations in Context: A Duch - Hungarian Comparison (pp. 113-137). Aldershot, UK: Ashgate.

Giles, H., Taylor, D. M., Lambert, W. E., Albert, G. (1976). Dimensions of ethnic identity: An example from Northern Maine. The Journal of Social Psychology, 100, 11-19.

Huddy, L. (2001). From social to political identity: A critical examination of social identity theory. Political Psychology, 1 (1), 127-155.

Kosterman, R., Feshbach, S. (1989). Toward a measure of patriotic and nationalistic attitudes. Political Psychology, 10() $2,257-274$.

Kroger, J. (2000). Identity Development: Adolescence Through Adulthood. London: Sage Publications.

Muldoon, O. T., Trew, K., Todd, J., Rougier, N., McLaughlin, K. (2007). Religious and national identity after the Belfast Good Friday Agreement. Political Psy- 
chology, 28 (1), 89-103.

Phinney J. S. (1990). Ethnic identity in adolescents and adults: Review of research. Psychological Bulletin, 108 (3), 499-514.

Phinney, J. S., Rosenthal, D. A. (1992). Ethnic identity development in adolescent children's ethnic socialization. In G. R. Adams, T. P. Gullotta, R. Montemayor (Eds.), Adolescent Identity Formation (pp. 145-172). Newbury Park, CA: Sage.

Phinney, J. S. (1989). Stages of ethnic identity in minority group adolescents. Journal of Early Adolescence, 9, $34-39$.
Salazar, J. M. (1998). Social identity and national identity. In S. Worchel, J. Morales, D. Paez, J. C. Deschamps (Eds.), Social Identity (pp. 1-23). London: Sage Publications.

Sears, D. O., Henry P. J. (1999). Ethnic identity and group threat in American politics. The Political Psychologist, 4 (2), $12-17$.

Transue, J. E. (2007). Identity salience, identity acceptance, and racial policy attitudes: American national identity as a uniting force. American Journal of Political Science, 51 (1), $78-91$.

\title{
UNIVERSITY STUDENTS AT THE CROSSROADS OF NATIONAL IDENTITY DECISIONS (EMPIRICAL APPROACH)
}

\author{
Dalia Antinienè \\ Kaunas University of Technology, Kaunas, Lithuania
}

\begin{abstract}
The article presents the research of attitudes that reflect national identity in Lithuanian student population. The aim of the research was to determine the subject matter and expression peculiarities of the national identity among Lithuanian students.

National identity attitudes were investigated with the help of an original, anonymous closed-type questionnaire. The attitudes that reflect national identity were presented by employing 33 statements. 712 students from nine universities, two colleges, and two institutions of higher education were surveyed in total.

The following dimensions of Lithuanian students' attitudes that reflect national identity were indicated with the help of factorial validation: "ethnocentricity", "reflective and democratic" attitude towards national identity, "moderate and rational" attitude towards national identity, "anti-ethnocentric" attitude towards national identity (relatively cosmopolitan), "nationalistic" attitude towards national identity (17.4\%). After the application of different factorial analysis models, the attitudes that reflect the national identity were revealed to polarize quite clearly into two following constituents that sometimes even contradicted each other: "modern" and "traditional" attitudes towards national identity.

Multidimensional Scaling (MDS) was used for the identification of total identity structure. A model of the gradation of the national identity expression was obtained, where several critical states of the student attitudes were clearly revealed.

With the help of K-Mean Cluster Analysis, particular statistical types of academic youth were identified in the research. Rather differently profiled groups of academic youth (depending on national identity) were found to exist. Four following statistical types of Lithuanian students were distinguished according to the expression of national identity attitudes: "modernists" "ethnocentrists", "dualists", and "indifferent".
\end{abstract}

Keywords: national identity, social attitudes, cosmopolitism, ethnocentrism.

Gauta 2007 m. lapkričio 13 d.

Received on November 13, 2007

Priimta 2008 m. vasario $20 \mathrm{~d}$.

Accepted on February 20, 2008
Dalia Antinienè

Kauno technologijos universitetas

(Kaunas University of Technology)

K. Donelaičio g. 20, LT-44239 Kaunas

Lietuva (Lithuania)

Tel +370 37771174

E-mail dalia.antinene@ktu.lt 